\title{
The study of melting process of the new plugging material at thermomechanical isolation technology of permeable horizons of mine opening
}

\author{
Andrii Sudakov ${ }^{1 *}$, Andrii Dreus ${ }^{2}$, Diana Sudakova ${ }^{1}$, and Oleksandr Khamininch ${ }^{2}$ \\ ${ }^{1}$ National Mining University, Department of Technic Prospecting of Deposits, 19 Yavornytskoho \\ Ave., 49005 Dnipro, Ukraine \\ ${ }^{2}$ Oles Honchar Dnipro National University, Department of Fluid Mechanics and Energy and Mass \\ Transfer, 72 Haharina Ave., 49010 Dnipro, Ukraine
}

\begin{abstract}
The article presents the results of experimental and theoretical studies, the purpose of which was to substantiate the technology of drilling wells isolation using new thermoplastic composite material. The basis of the proposed material is gravel, and secondary polyethylene terephthalate acts as a binding material. The use of the proposed insulation material avoids a number of disadvantages specific for traditional grouting mortars. The technology of material application provides its melting in a well by thermomechanical drilling. The article deals with the issues, related to the substantiation of the optimal formulation of a thermoplastic composite material based on secondary polyethylene terephthalate, and the determination of rational operating parameters of thermomechanical drilling, which allow to melt effectively the material at the bottom of a well. The possibility of material application for the insulation of absorbing horizons in borehole conditions has been proved. Based on the analysis of the heat balance at the bottom of a well, the calculation procedure has been proposed and the dependences of the velocity and time of thermomechanical melting of the grouting thermoplastic composite material on the operating parameters of drilling, thermal properties and geometric characteristics of the drill bit, have been determined.
\end{abstract}

\section{Introduction}

Drilling of exploring and production wells in order to explore deposits and extract mineral resources in the area of iron ore and coal basins is conducted in a high degree of development and metamorphism, in strong and fractured rocks [1-10]. The rocks of the developed horizons are in a highly stressed state [11-18], what makes the technology of mine workings constructions more complicated [19-22]. Absorption of drilling fluids is one of the most common complications in drilling wells [23]. Elimination of this complication, leads to significant material and time costs. The main method of controlling

\footnotetext{
*Corresponding author: sudakovy@ukr.net
} 
the absorption of drilling fluids is the isolation of fractured walls of wells with the help of oil wells. Most of these materials are produced on a water basis with the introduction of mineral-binding or synthetic substances, mainly cement mortars. The effectiveness of such solutions is low due to the fact that they have a high sensitivity to dilution with water [24]. In practice, when the absorption of washing liquid is eliminated with cement mortars, tons, tens of tons of cement are used [25].

The low efficiency of conventional well pumping technology forces researchers to look for both new materials and technologies to prevent drilling fluid losses [26-30]. In particular, the promising direction is the use of grouting mortars based on thermoplastic materials with a low melting point, the melt of which can easily penetrate into the absorption channels of the washing liquid and harden there.

These materials are sufficiently durable waterproofing material, which have high corrosion resistance in aggressive environments. One of this kind of technologies ensuring an increase in the reliability of insulation works, improvement of working conditions and a significant reduction in material costs for the tamponing of complication zones was developed at the National Technical University [31].

The idea of the work is to use briquetted plugging thermoplastic composite materials (TPCM) delivered to the absorption zone followed by thermomechanical melting. The resulting melt of the TPCM penetrate into the absorption channels of the washing liquid solidifies there and forms an impermeable insulation shell around the borehole of the borehole.

Therefore, for the practical implementation of this technology, it is necessary to determine the rational parameters of the thermomechanical melting process. In this article are presented the results of experimental bench and theoretical studies of the thermomechanical melting of TPCM serving as a justification for the thermomechanical technology of isolating the absorbing horizons of boreholes.

\section{Methods of the research}

Bench testings. Technological modes of the process of thermomechanical melting of the oil-filled material during the plugging of the permeable horizon with the use of TPCM, which determined by physical modeling methods in bench conditions [32 - 39].

With this purpose there are developed and invented experimental bench with the count of the similar criteries (Fig. 1), including the ZIF-650M drill rig with a continuously variable drive 4 , the absorbing horizon model 3 and the measuring and computing complex 1, the model of the laboratory thermomechanical drill bit (Fig. 2), which allowed for thermomechanical melting at the bottom of the well to create power from 1.7 to $5.8 \mathrm{~kW}$.

Bench examinations were conducted in two stages.

At the first stage, the optimal combination of the regime parameters of the board process for the various TPCM formulations was worked out. For this purpose, TPCM blocks with different component ratios were made.

At the second stage, during thermomechanical melting of TPCM under the conditions of the absorbing horizon model, it was determined that:

- melting temperature of the melt of TPCM;

- penetrating ability and spreading of the melt along the channels of absorption of the washing liquid, depending on the crack opening.

TPCM is a cylindrical briquette (Fig. 3), consisting of a solidified mixture of gravel and secondary crystalline polyethylene terephthalate (PET).

Theoretical studies of the process of thermomechanical melting of TPCM were carried out using mathematical modeling methods. 


\section{Results of the research}

In a result of bench studies, optimal combinations of the mode parameters of the thermomechanical melting technology of TPCM have been determined, that ensure the contact heating and melting of the oil well with minimal time and high drilling rates.

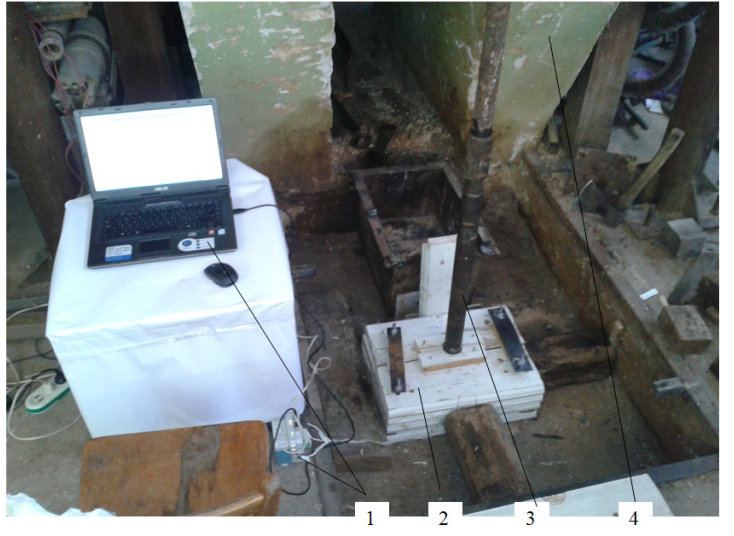

Fig. 1. General view of the stand:1 - measuring and computing complex; 2 - the model of absorbing horizon with spacers; 3 - a string of drill pipes; 4 - base of the drilling rig.

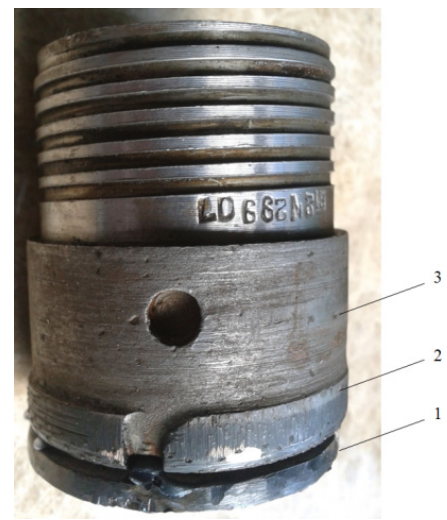

Fig. 2. Thermomechanical drill bit: 1 - friction plate; 2 - matrix; 3 drill bit body.

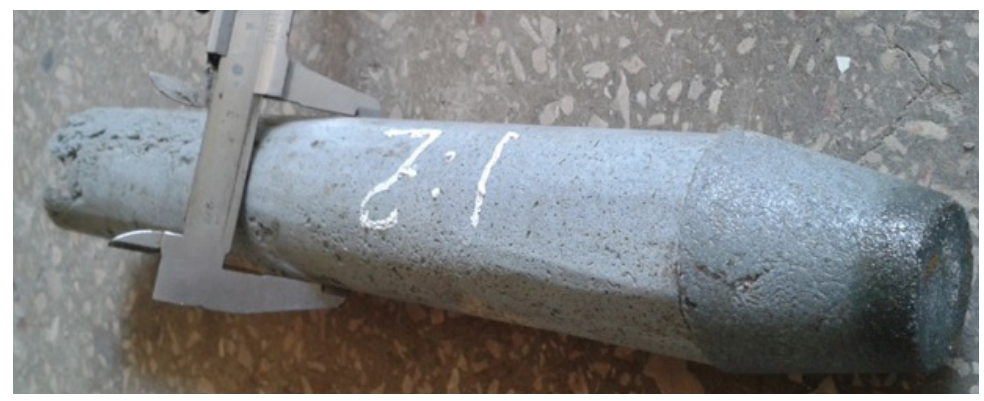

Fig. 3. General view of TPCM blocks.

As a conclusion of the research, it follows that:

- the rate of thermomechanical melting, regardless of the binder to filler ratio, as well as the TPCM formula for the regime parameters, is of the same order of magnitude (Table 1):

- at a ratio of PET to gravel of $1: 1$, the rate of thermomechanical drilling (melting) varies from 0.4 to $0.9 \mathrm{~m} / \mathrm{h}$;

- at a ratio of PET to gravel of 1:2, the rate of thermomechanical drilling (melting) varies from 0.4 to $0.7 \mathrm{~m} / \mathrm{h}$;

- at a ratio of PET to gravel of 1:3, the thermomechanical drilling speed (melting) varies from 0.8 to $1.7 \mathrm{~m} / \mathrm{h}$;

- at a ratio of PET to gravel of $1: 4$, the rate of thermomechanical drilling (melting) varies from 0.3 to $0.7 \mathrm{~m} / \mathrm{h}$;

- when TPCM is melting, the temperature of its heating did not exceed the critical value (3000C) at which the astringent is destructed;

- the time of heating of the TPCM to its melting point depends on the TPCM formulation; 
- the temperature rise in the sample of TPCM to the melting temperature takes place in the contact zone of the tool working part.

Table 1. Results of determination of technological parameters of thermomechanical drilling TPCM.

\begin{tabular}{|c|c|c|c|c|c|c|c|c|c|c|c|c|c|c|c|}
\hline 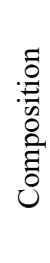 & $\begin{array}{l}\vec{\Xi} \\
\approx \\
\approx\end{array}$ & $\begin{array}{l}Z \\
\text { Z } \\
2 \\
2\end{array}$ & 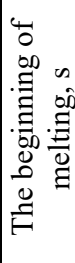 & 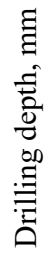 & 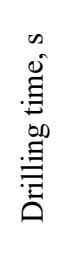 & 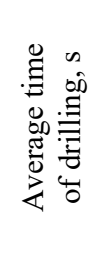 & 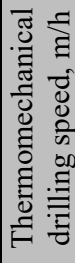 & 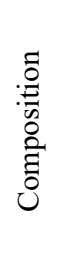 & $\begin{array}{l}\bar{\Xi} \\
\therefore\end{array}$ & $\begin{array}{l}Z \\
\text { Z } \\
0 \\
2\end{array}$ & 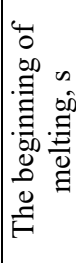 & 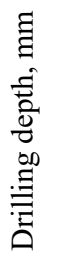 & 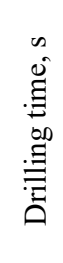 & 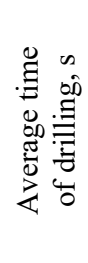 & 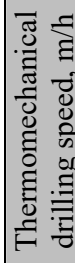 \\
\hline \multirow{18}{*}{ 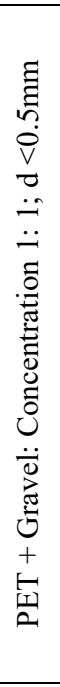 } & \multirow{6}{*}{300} & \multirow{3}{*}{500} & 90 & \multirow{3}{*}{50} & 467 & \multirow{3}{*}{461.0} & \multirow{4}{*}{0.4} & \multirow{7}{*}{ 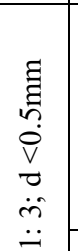 } & \multirow{6}{*}{300} & \multirow{3}{*}{500} & 8 & \multirow{3}{*}{50} & 357 & \multirow{3}{*}{355.7} & \multirow{3}{*}{0.5} \\
\hline & & & 91 & & 445 & & & & & & 8 & & 355 & & \\
\hline & & & 88 & & 471 & & & & & & 8 & & 355 & & \\
\hline & & \multirow{3}{*}{700} & 50 & \multirow{3}{*}{50} & 361 & \multirow{3}{*}{358.7} & & & & \multirow{3}{*}{700} & 8 & \multirow{3}{*}{50} & 142 & \multirow{3}{*}{143.7} & \multirow{3}{*}{1.3} \\
\hline & & & 50 & & 352 & & \multirow[t]{3}{*}{0.5} & & & & 8 & & 140 & & \\
\hline & & & 52 & & 363 & & & & & & 8 & & 149 & & \\
\hline & \multirow{6}{*}{500} & \multirow{3}{*}{500} & 40 & \multirow{3}{*}{50} & 326 & & & & & & 6 & & 155 & & \\
\hline & & & 40 & & 320 & 323.0 & 0.6 &.$\stackrel{0}{\Xi}$ & & 500 & 5 & 50 & 152 & 154.3 & 1.2 \\
\hline & & & 41 & & 323 & & & $\stackrel{\pi}{\Xi}$ & 500 & & 6 & & 156 & & \\
\hline & & & 25 & & 269 & & & $\overline{0}$ & 500 & & 5 & & 119 & & \\
\hline & & 700 & 23 & 50 & 270 & 269.7 & 0.7 & ธี & & 700 & 6 & 50 & 121 & 117.7 & 1.5 \\
\hline & & & 25 & & 270 & & & & & & 6 & & 113 & & \\
\hline & & & 27 & & 320 & & & $\overline{0}$ & & & 5 & & 142 & & \\
\hline & & 500 & 27 & 50 & 336 & 327.0 & 0.6 & ङేँ & & 500 & 5 & 50 & 144 & 142,3 & 1.3 \\
\hline & 700 & & 27 & & 325 & & & & 700 & & 5 & & 141 & & \\
\hline & 100 & & 11 & & 204 & & & 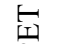 & 100 & & 5 & & 101 & & \\
\hline & & 700 & 10 & 50 & 200 & 203.3 & 0.9 & $\bar{a}$ & & 700 & 5 & 50 & 106 & 104.0 & 1.7 \\
\hline & & & 11 & & 206 & & & & & & 5 & & 105 & & \\
\hline & & & 15 & & 417 & & & & & & 10 & & 555 & & \\
\hline & & 500 & 14 & 50 & 420 & 418.7 & 0.4 & & & 500 & 10 & 50 & 550 & 553.7 & 0.3 \\
\hline $\bar{\Xi}$ & & & 15 & & 419 & & & $\bar{n}$ & & & 9 & & 556 & & \\
\hline$\stackrel{?}{v}$ & 300 & & 11 & & 310 & & & $\stackrel{v}{v}$ & 300 & & 8 & & 492 & & \\
\hline$\tau$ & & 700 & 10 & 50 & 305 & 307.7 & 0.6 & $\nabla$ & & 700 & 8 & 50 & 490 & 490.7 & 0.4 \\
\hline$\ddot{i}$ & & & 10 & & 308 & & & $\ddot{\forall}$ & & & 8 & & 490 & & \\
\hline$\ddot{\ddot{z}}$ & & & 18 & & 357 & & & $\ddot{\ddot{g}}$ & & & 7 & & 408 & & \\
\hline. & & 500 & 18 & 50 & 350 & 355.0 & 0.5 & .0 & & 500 & 6 & 50 & 403 & 410,7 & 0.4 \\
\hline 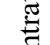 & 500 & & 17 & & 358 & & & $\stackrel{\pi}{\Xi}$ & 500 & & 6 & & 421 & & \\
\hline లี & 500 & & 12 & & 309 & & & ల్ల & 500 & & 5 & & 314 & 317.3 & \\
\hline రే & & 700 & 13 & 50 & 315 & 311.3 & 0.6 & క & & 700 & 5 & 50 & 320 & & 0.6 \\
\hline$\ddot{-}$ & & & 12 & & 310 & & & & & & 5 & & 318 & & \\
\hline $\bar{\Xi}$ & & & 10 & & 260 & & & $\overline{8}$ & & & 5 & & 250 & 259.7 & \\
\hline है & & 500 & 9 & 50 & 261 & 258.7 & 0.7 & 苛 & & 500 & 5 & 50 & 266 & & 0.7 \\
\hline+ & 700 & & 9 & & 255 & & & ${ }_{T}^{\top}$ & & & 5 & & 263 & & \\
\hline 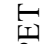 & 100 & & 5 & & 248 & & & 鳬 & 100 & & 5 & & 251 & & \\
\hline $\bar{\Sigma}$ & & 700 & 5 & 50 & 250 & 246.3 & 0.7 & $\bar{\Sigma}$ & & 700 & 5 & 50 & 250 & 250.7 & 0.7 \\
\hline & & & 5 & & 241 & & & & & & 5 & & 251 & & \\
\hline
\end{tabular}

The results of bench modeling have shown the possibility of obtaining a monolithic plugging stone, the appearance of which is shown in Fig. 4.

Taking into account the results of bench studies of the thermomechanical drilling speed (melting) of TPCM, TPCM with a component ratio of 1:1 is recommended for use in 
downhole conditions.

Theoretical research. For the theoretical determination of the thermomechanical melting speed of TPCM, a mathematical model was developed on the basis of the heat balance equation on the contact surface (Fig. 5).

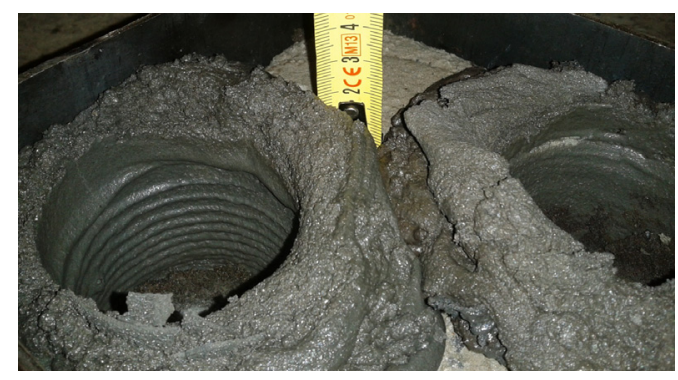

Fig. 4. The view of the melt (plaster stone) obtained at a rotation frequency of $500 \mathrm{~min}^{-1}$ and an axial load equal to $700 \mathrm{daN}$, for TPCM with a component ratio of 1:3.

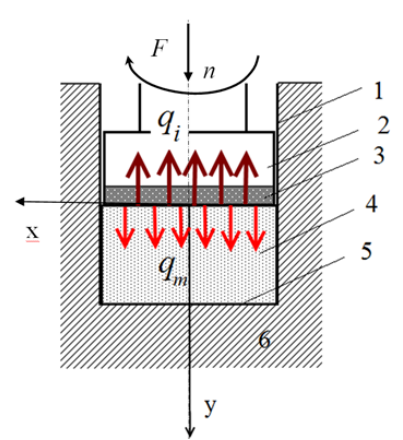

Fig. 5. Scheme to calculation of thermomechanical melting by friction: $1-$ well walls; 2 - thermomechanical drill bit; 3 - friction plate; 4 - block TPCM; 5 hole bottom; 6 - rock.

The heat flow is generated at the contact line of the friction plate 3 and the surface of the TPCM briquette during the operation of the thermomechanical drill bit 2 . The generating heat flow is distributed to the body of the TPCM briquette due to thermal conductivity. Under the influence of thermal energy - TPCM heats up. After the temperature of the contact surface has reached the value of the phase transition (melting point) - the material begins to melt. The molten part of the material is crushed into the porous walls of the well 1 , due to the pressure created by the drill bit.

To determine the rate of thermomechanical drilling (melting), the heat balance equation is used in the form:

$$
q_{m}=q_{m e l t}+q_{\lambda}
$$

where $q$ heat going to the melting of the surface layer of the material with a thickness of $d_{\xi}$ for a time $d_{\tau}, q_{\lambda}$ is the heat flow, going to the heating of the inner layers of the material, determined by the Fourier law. The heat flow $q_{\text {melt }}$ is given by:

$$
q_{m e l t}=\rho L \frac{d_{\xi}}{d_{\tau}},
$$

where $L$ is the latent heat of fusion of TPCM. The speed of thermomechanical drilling is defined as $V=d_{\xi} / d_{\tau}$.

The heat flow on the working surface is determined from:

$$
q_{m}=\frac{\mu k_{m} \pi F D n}{S},
$$

where $\mu$ is the coefficient of friction; $k_{m}$ is the coefficient taking into account the fraction of the heat of friction going to the heating and melting of the TPCM; $F$ is the axial load; $D$ is the diameter of the friction surface; $S$ is the friction surface area; $n$ is the drill bit rotation speed. 
The solution of the non-stationary problem for determining the surface temperature of an isotropic semi-infinite body when heated by a heat flux is presented in [40]. Using this solution and (3) it is easy to obtain an expression that establishes a relationship between the process parameters of the process and the parameters of the thermophysical processes during tool operation:

$$
F n=\frac{\lambda D}{2 \mu k_{m} \sqrt{\pi a \tau_{f f}}}\left(t_{f}-t_{0}\right)
$$

where $\tau_{f}$ is the surface heating time to the melting point; $t_{f}$ the melting temperature of the TPCM; $a$ is the coefficient of thermal diffusivity of the TPCM.

Since the temperature on the surface after the beginning and throughout the melting process is constant and equal to $t_{f}$. In this case, the temperature field in a semi-infinite body is described by the expression [41 - 43]:

$$
t=t_{f}+\left(t_{0 f}-t_{f}\right) \operatorname{erf}\left(\frac{y}{2 \sqrt{a \tau}}\right)
$$

where $t_{0 f}$ is the temperature field, which was formed in the workpiece at the beginning of the melting process. We note that the entrainment of the mass of the melt from the contact surface leads to a restructuring of the temperature field at each instant of time, and expression (5) can not be used for a rigorous investigation of thermal processes in thermomechanical melting. Therefore, further reasoning will be approximate. Using (5) we can determine:

$$
q_{\lambda}=-\left.\lambda \frac{\partial t}{\partial y}\right|_{y=0}=-\lambda\left(t_{0 f}-t_{f}\right) \frac{e^{-\frac{y^{2}}{4 a \tau}}}{\sqrt{\pi a \tau}}=-\frac{\lambda\left(t_{0 f}-t_{f}\right)}{\sqrt{\pi a \tau}} .
$$

After all, from equation (1), taking into account (4), (6) we obtain:

$$
q_{m e l t}=\frac{2 \lambda\left(t_{f}-t_{0}\right)}{\sqrt{\pi a \tau_{f}}}-\frac{\lambda\left(t_{0 f}-t_{f}\right)}{\sqrt{\pi a \tau}}=\frac{\lambda}{\sqrt{\pi a}}\left(\frac{2\left(t_{f}-t_{0}\right)}{\sqrt{\tau_{f}}}+\frac{t_{f}-t_{f 0}}{\sqrt{\tau}}\right) .
$$

Therefore the drilling speed is expressed by:

$$
V=\frac{\lambda}{\rho L \sqrt{\pi a}}\left(\frac{2\left(t_{f}-t_{0}\right)}{\sqrt{\tau_{f}}}+\frac{t_{f}-t_{0}}{\sqrt{\tau}}\right)
$$

For the practical use (8), it is necessary to know the temperature $t_{0_{f}}$, which is the function of the coordinate. Suppose that the temperature in the bulk of the thermoplastic material at the beginning of the melting process is slightly different from the initial temperature $t_{0} \approx t_{0}$. This assumption is based on the fact that the heating time $\tau_{f}$, as a rule, is one order of magnitude shorter than the time of thermomechanical drilling, the thermal conductivity coefficient of TPCM is a small value. In this case, formula (8) can be written in the form: 


$$
V=\frac{\lambda\left(t_{f}-t_{0}\right)}{\rho L \sqrt{\pi a}}\left(\frac{2}{\sqrt{\tau_{f}}}+\frac{1}{\sqrt{\tau}}\right) .
$$

Determining $\tau_{f}$ through the regime parameters of drilling using (4), we obtain:

$$
V=\frac{1}{\rho L}\left(\frac{4 \mu k_{m} F n}{D}+\frac{\lambda\left(t_{f}-t_{0}\right)}{\sqrt{\pi a \tau}}\right) .
$$

The average speed of thermomechanical drilling during the time $T$ is defined as:

$$
V_{a v}=\frac{1}{\mathrm{~T}} \int_{0}^{\mathrm{T}} V(\tau) \mathrm{d} \tau
$$

where $V(\tau)$ it is defined by the expression (10).

After integrating (10) with the range in time from 0 to $T$, taking into account the condition $\xi=0$ for $\tau=0$, we obtain the expression for drilling depth for the period $T$ :

$$
h=\frac{1}{\rho L}\left(\frac{4 \mu k_{m} F n}{D} \mathrm{~T}+\frac{2 \lambda\left(t_{f}-t_{0}\right)}{\sqrt{\pi a}} \sqrt{\mathrm{T}}\right) .
$$

The results of calculating the depth of drilling are shown in Fig. 6 and the rate of thermomechanical melting of TPCM in the form of the nomogram in Fig. 7, for a thermomechanical drill bit with a diameter of $59 \mathrm{~mm}$.

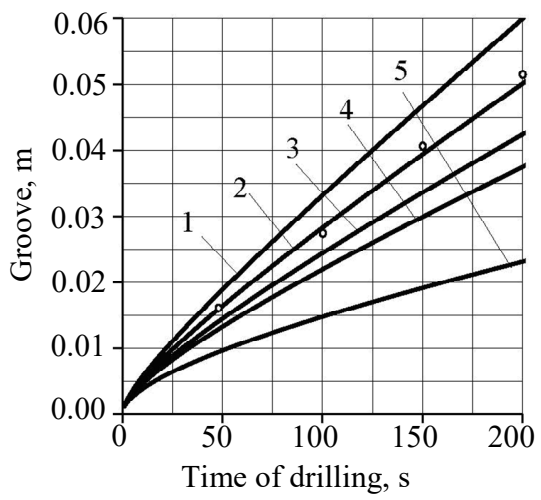

Fig. 6. Calculation dependence of the change in the depth of the thermomechanical melting of the borehole in time on tool dimensions, with an axial load of $700 \mathrm{daN}$ and a rotation speed of $700 \mathrm{~min}^{-1}$ : $1-46 \mathrm{~mm} ; 2-59 \mathrm{~mm} ; 3-76 \mathrm{~mm} ; 4-93 \mathrm{~mm}$; $5-269 \mathrm{~mm}$; o- experimental results.
Termomechanical melting

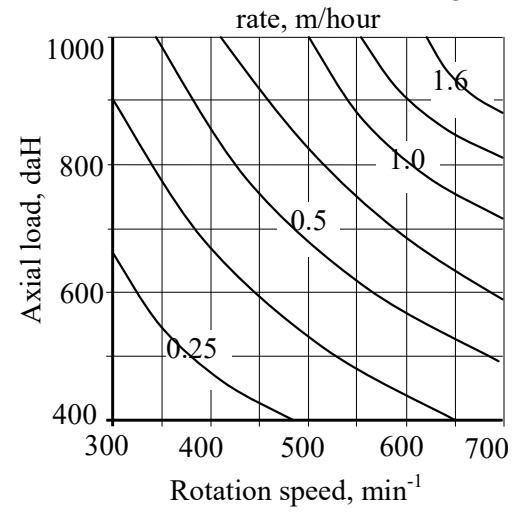

Fig. 7. The calculated dependence of the stationary thermomechanical melting rate of TPCM on the value of the regime parameters.

With an axial load of $700 \mathrm{daN}$ and a speed of $700 \mathrm{~min}^{-1}$, the design speed of thermomechanical melting with a drill bit with a diameter of $46 \mathrm{~mm}$ is $-1.2 \mathrm{~m} / \mathrm{h} ; 59 \mathrm{~mm}-$ $1.0 \mathrm{~m} / \mathrm{h} ; 76 \mathrm{~mm}-0.84 \mathrm{~m} / \mathrm{h} ; 93 \mathrm{~mm}-0.74 \mathrm{~m} / \mathrm{h} ; 269 \mathrm{~mm}-0.46 \mathrm{~m} / \mathrm{h}$. The discrepancy between the results of analytical and bench studies did not exceed $10 \%$. 
Taking into account the thermophysical characteristics of the TPCM and the drill bit, the rate of thermomechanical melting of TPCM and the regularity of the temperature propagation in the TPCM are determined, as well as the regime parameters of the thermomechanical technology for eliminating the absorption of the washing liquid.

\section{Conclusions}

The possibility of using TPCM as a plugging material for drilling wells has been proved.

As a result of experimental studies and numerical calculations, it is shown, that the rate of thermomechanical melting of TPCM depends on the ratio of the constituent components.

For application in undergroud conditions, TPCM with a component ratio of $1: 1$ is recommended, in combination with an axial load of at least $700 \mathrm{daN}$ with a drill bit rotation speed of $700 \mathrm{~min}^{-1}$.

Approximate analytical relationships are obtained for calculating the rate of thermomechanical melting of the TPCM at the bottom, depending on the operating parameters of the drilling, the geometry of the drill bit, and the thermophysical properties of the material.

Authors express gratitude for the help and consultations during work performing for director of LTD Industrially-geological group "Dniprohidrobud" of Oleh Mostinets.

\section{References}

1. Bondarenko, V., Kovalevs'ka, I., \& Fomychov, V. (2012). Features of carrying out experiment using finite-element methodat multivariate calculation of mine massif - combined support system. Geomechanical Processes During Underground Mining, 7-13. https://doi.org/10.1201/b13157-3

2. Bondarenko, V.I., Kharin, Ye.N., Antoshchenko, N.I., \& Gasyuk, R.L. (2013). Basic scientific positions of forecast of the dynamics of methane release when mining the gas bearing coal seams. Naukovyi Visnyk Natsionalnoho Hirnychoho Universytetu, (5), 24-30.

3. Dychkovskyi, R.O., Lozynskyi, V.H., Saik, P.B., Petlovanyi, M.V., Malanchuk, Ye.Z., \& Malanchuk, Z.R. (2018). Modeling of the disjunctive geological fault influence on the exploitation wells stability during underground coal gasification. Archives of Civil and Mechanical Engineering, 18(4), 1183-1197. https://doi.org/10.1016/j.acme.2018.01.012

4. Bondarenko, V., Maksymova, E., \& Koval, O. (2013). Genetic classification of gas hydrates deposits types by geologic-structural criteria. Annual Scientific-Technical Collection-Mining of Mineral Deposits, 115-119. https://doi.org/10.1201/b16354-21

5. Kovalevska, I., Symanovych, H., Barabash, M., \& Snihur, V. (2017). Research intro rock pressure manifestations in interstratal rocks during descending and simultaneous mining of $\mathrm{C}_{9}$ and $\mathrm{C}_{10}{ }^{\text {top }}$ coal seams. Mining of Mineral Deposits, 11(1): 50-56. https://doi.org/10.15407/mining11.01.050

6. Khomenko, O., Kononenko, M., Myronova, I., \& Sudakov, A. (2018). Increasing ecological safety during underground mining of iron-ore deposits deposits. Naukovyi Visnyk Natsionalnoho Hirnychoho Universytetu, (2), 29-38.

7. Bondarenko, V., Svietkina, O., \& Sai, K. (2018). Effect of mechanoactivated chemical additives on the process of gas hydrate formation. Eastern-European Journal of Enterprise Technologies, 1(6(91)), 17-26. https://doi.org/10.15587/1729-4061.2018.123885

8. Kovalevs'ka, I., Symanovych, G., \& Fomychov, V. (2013). Research of stress-strain state of cracked coal-containing massif near-the-working area using finite elements technique. Annual ScientificTechnical Collection - Mining of Mineral Deposits, 159-163. https://doi.org/10.1201/b16354-28

9. Lozynskyi, V.H., Dychkovskyi, R.O., Falshtynskyi, V.S., \& Saik, P.B. (2015). Revisiting possibility to cross disjunctive geological faults by underground gasifier. Naukovyi Visnyk Natsionalnoho Hirnychoho Universytetu, (4), 22-28. 
10. Sdvizhkova, Ye.A., Babets, D.V., Smirnov, A.V. (2014). Support loading of assembly chamber in terms of western donbas plough longwall. Naukovyi Visnyk Natsionalnoho Hirnychoho Universytetu, (5), 26-32.

11. Falshtyns'kyy, V., Dychkovs'kyy, R., Lozyns'kyy, V., \& Saik, P. (2013). Justification of the gasification channel length in underground gas generator. Annual Scientific-Technical Collection - Mining of Mineral Deposits, 125-132. https://doi.org/10.1201/b16354-23

12. Kovalevs'ka, I., Illiashov, M., Fomychov, V., \& Chervatuk, V. (2012). The formation of the finite-element model of the system "undermined massif - support of stope". Geomechanical Processes during Underground Mining, 73-79. https://doi.org/10.1201/b13157-13

13. Kyrychenko, Y., Samusia, V., Kyrychenko, V., \& Goman, O. (2012). Experimental investigation of aeroelastic and hydroelastic instability parameters of a marine pipeline. Geomechanical Processes During Underground Mining: School of Underground Mining 2012, 163-167.

14. Falshtynskyy, V., Dychkovskyy, R., Lozynskyy, V., \& Saik, P. (2012). New method for justification the technological parameters of coal gasification in the test setting. Geomechanical Processes During Underground Mining, 201-208. https://doi.org/10.1201/b13157-35

15. Saik, P.B., Dychkovskyi, R.O., Lozynskyi, V.H., Malanchuk, Z.R., \& Malanchuk, Ye.Z. (2016). Revisiting the underground gasification of coal reserves from contiguous seams, Naukovyi Visnyk Natsionalnoho Hirnychoho Universytetu, (6), 60-66.

16. Pivnyak, G., Dychkovskyi, R., Smirnov, A., \& Cherednichenko, Y. (2013). Some aspects on the software simulation implementation in thin coal seams mining. Energy Efficiency Improvement of Geotechnical Systems, 1-10. https://doi.org/10.1201/b16355-2

17. Kovalevska, I., Barabash, M., \& Snihur, V. (2018). Development of a research methodology and analysis of the stress state of a parting under the joint and downward mining of coal seams. Mining of Mineral Deposits, 12(1), 76-84. https://doi.org/10.15407/mining12.01.076

18. Khomenko, O. (2012). Implementation of energy method in study of zonal disintegration of rocks. Naukovyi Visnyk Natsionalnoho Hirnychoho Universytetu, (4), 44-54.

19. Zhanchiv, B., Rudakov, D., Khomenko, O., \& Tsendzhav, L. (2013). Substantiation of mining parameters of Mongolia uranium deposits. Naukovyi Visnyk Natsionalnoho Hirnychoho Universytetu, (4), 10-18.

20. Khomenko, O., Kononenko, M., \& Myronova, I. (2013). Blasting works technology to decrease an emission of harmful matters into the mine atmosphere. Annual Scientific-Technical Collection - Mining of Mineral Deposits, 231-235. https://doi.org/10.1201/b16354-43

21. Vladyko, O., Kononenko, M., \& Khomenko, O. (2012). Imitating modeling stability of mine workings. Geomechanical Processes During Underground Mining, 147-150. https://doi.org/10.1201/b13157-26

22. Khomenko, O., Tsendjav, L., Kononenko, M., \& Janchiv, B. (2017). Nuclear-and-fuel power industry of Ukraine: production, science, education. Mining of Mineral Deposits, 11(4), 86-95. https://doi.org/10.15407/mining11.04.086

23. Cook, J., Growcock, F., Guo, Q., Hodder, M., \& van Oort, E. (2011). Stabilizing the wellbore to prevent lost circulation. Oilfield Review, 23(4), 26-35.

24. Ashok Kumar Santra, B.R. Reddy, \& Mfon Antia. (2007). Designing Cement Slurries for Preventing Formation Fluid Influx After Placement. International Symposium on Oilfield Chemistry, 28 February-2 March, Houston, Texas, U.S.A. SPE-106006-MS. https://doi.org/10.2118/106006-MS

25. Fedorov, B., Ratov, B., \& Sharauova, A. (2017). Development of the model of petroleum well boreability with PDC bore bits for Uzen oil field (the Republic of Kazakhstan) Eastern-European Journal of Enterprise Technologies, 3(1(87), 16-22. https://doi.org/10.15587/1729$\underline{4061.2017 .99032}$

26. Brazhenenko A.M., Goshovskiy S.V., \& Sudakov, A.K. (2007). Tamponazh gornykh porod pri burenii geologorazvedochnykh skvazhin legko-plavkimi materialami. Kyiv: Ukrainskyi derzhavnyi heoloho-rozviduvalnyi instytut. 
27. Yu, H., Li, L., Zheng, J., Ji, W., Qin, X., Fu, X., \& Gao, W. (2016). New Method of Steam Channeling Plugging in Horizontal Wells of Heavy Oil Steam Stimulation. In SPE Latin America and Caribbean Heavy and Extra Heavy Oil Conference. SPE-181173-MS.

28. Liu, Y., Song, T., \& Xu, Y. (2016). A new evaluation method for micro-fracture plugging in hightemperature deep wells and its application: A case study of the Xushen Gas Field, Songliao Basin. Natural Gas Industry B, 3(2), 158-164.

29. Sudakov, A.K., Dreus, A.Yu., Khomenko O.Ye., \& Sudakova. D.A. (2017). Analitic study of heat transfer in absorbing horizon of boreholes in the formation of protection cryogenic plugging material. Naukovyi Visnyk Natsionalnoho Hirnychoho Universytetu, 3(159), 32-46.

30. Sudakov, A., Dreus, A., Ratov, B., \& Delikesheva, D. (2018). Theoretical bases of isolation technology for swallowing horizons using thermoplastic materials. News of the national academy of sciences of the republic of Kazakhstan, 2(428), 72-80.

31. Kuzin, J., Isakova, M., Sudakova, D., \& Mostinets, O. (2017). Isolation technology for swallowing zones by thermoplastic materials on the basis of polyethyleneтerephthalate. Naukovyi Visnyk Natsionalnoho Hirnychoho Universytetu, (1), 34-39.

32. Kozhevnikov, A.A., Dreus, A.J., Lysenko, K.Ye., \& Sudakov, A.K. (2013). Research of heat transfer in cryogenic gravel filter at his transporting on barrel of drillhole. Naukovyi Visnyk Natsionalnoho Hirnychoho Universytetu, (6), 49-54.

33. Dreus, A., Sudakov, A.K., \& Kozhevnikov, A.A. (2016). Investigation of heating of the drilling bits and definition of the energy efficient drilling modes. Eastern-European Journal of Enterprise Technologies. Technologies, 3(7(81)), 41-46.

34. Ziborov, K.A., Protsiv, V.V., Blokhin, S.Ye., \& Fedoriachenko, S.O. (2014) Applicability of computer simulation while designing mechanical systems of mining rolling stock. Naukovyi Visnyk Natsionalnoho Hirnychoho Universytetu, (6), P. 55-59.

35. Sudakov, A.K. Khomenko O.Ye., Isakova M. L., \& Sudakova, D.A. (2016). Concept of numerical experiment of isolation of absorptive horizons by thermoplastic materials. Naukovyi Visnyk Natsionalnoho Hirnychoho Universytetu, 5(155), 12-16.

36. Protsiv, V., Ziborov, K., \& Fedoriachenko, S. (2013) On formation of kinematical and dynamical parameters of output elements of the mine vehicles in transient motion. Naukovyi Visnyk Natsionalnoho Hirnychoho Universytetu, (4), 65-70.

37. Dreus, A.J., Sudakov, A.K., Kozhevnikov, A.A., \& Vahalin, J.M. (2016). Study on thermal strength reduction of rock formation in the diamond core drilling process using pulse flushing mode. Naukovyi Visnyk Natsionalnoho Hirnychoho Universytetu, 3(153), 5-9.

38. Khomenko, O.Ye., Sudakov, A.K., Malanchuk, Z.R., \& Malanchuk, Ye.Z. (2017). Principles of rock pressure energy usage during underground mining of deposits. Naukovyi Visnyk Natsionalnoho Hirnychoho Universytetu, 2(158), 34-43.

39. Kozhevnykov, A.O., Dreus, A.Yu., Baochang, Liu, \& Sudakov, A.K. (2018). Drilling fluid circulation rate infuence on the contact temperature during borehole drilling. Naukovyi Visnyk Natsionalnoho Hirnychoho Universytetu, 1(163), 35-43.

40. Franchuk, V.P., Ziborov, K.A., Krivda, V.V., Fedoriachenko, S.O. (2017). On wheel rolling along the rail regime with longitudinal load. Naukovyi Visnyk Natsionalnoho Hirnychoho Universytetu, (3), 62-67.

41. Polezhaev, Yu.V., \& Yurevich, F.B. (1976). Thermal protection. Moskva: Energiya.

42. Sundén, B. (2012). Introduction to heat transfer. Southampton: WIT Press.

43. Dreus, A.Yu., \& Lysenko, K.Ye. (2016). Computer simulation of fluid mechanics and heat transfer processes at the working face of borehole. Naukovyi Visnyk Natsionalnoho Hirnychoho Universytetu, (5), 29-35. 